\title{
Implementasi Penggunaan Quizizz dalam Evaluasi Pembelajaran Online English For Food and Beverage Service
}

\section{Ni Luh Supartini1*, Luh Eka Susanti2}

1,2 Institut Pariwisata dan Bisnis Internasional, Denpasar, Indonesia

\section{ART ICLE INFO}

\section{Article history:}

Received September 09, 2021

Revised September 10, 2021

Accepted October 14, 2021

Available online October 25, 2021

Kata Kunci:

Quizizz, Evaluasi, E-learning

Keywords:

Quizizz, Evaluation, E-learning

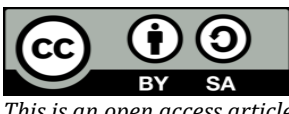

This is an open access article under the CC BY-SA license.

Copyright (C) 2021 by Author.

Published by Universitas Pendidikan Ganesha.

\begin{abstract}
A B S T R A K
Penggunaan media pembelajaran berbasis teknologi yang tepat sangat dibutuhkan untuk menunjang proses pembelajaran daring. Salah satu medai yang dapat digunakan yakni aplikasi Quizizz yang bisa dipakai secara langsung dan bersamaan dengan Learning Management System. Adapun tujuan dari penelitian ini yakni untuk mengidentifikasi bagaimana implementasi Quizizz dalam evaluasi pembelajaran online pada English For Food And Beverage Service. Penelitian ini merupakan jenis penelitian deskriptif kualitatif yang dilakukan untuk memperoleh informasi mengenai keadaan saat ini. Subjek yang terlibat pada penelitian ini yakni sebanyak 60 mahasiswa dari program studi Manajemen Perhotelan. Pengumpulan data dalam penelitian dilakukan dengan metode wawancara, kuesioner dan observasi dengan metode analisis data secara deskriptif. Hasil analisis penelitian menunjukkan bahwa implementasi penggunaan Quizizz sangat membantu mahasiswa dalam mengingat kembali semua materi yang disampaikan secara online dan meningkatkan minat belajar Bahasa Inggris mahasiswa. Hal ini didukung oleh hasil analisis kuisioner yang menunjukkan bahwa $78,4 \%$ mahasiswa menyatakan setuju untuk penggunaan Quizizz menarik minat mereka untuk belajar bahasa Inggris. Hanya 21,65\% mahasiswa yang merass cukup setuju. Dan tidak ada mahasiswa yang menyatakan bahwa Quizizz ini tidak meningkatkan minat mereka untuk mengikuti perkuliahan. Sehingga dapat disimpulkan bahwa aplikasi Quizizz sangat efektif digunakan untuk membantu mahasiswa dalam proses pembelajaran daring serta dapat mempermudah proses evaluasi pembelajaran oleh dosen.
\end{abstract}

\section{A B S T RACT}

Appropriate technology-based learning media is needed to support the online learning process. One of the media that can be used is the Quizizz application which can be used directly and simultaneously with the Learning Management System. The purpose of this study is to identify how to implement Quizizz in evaluating online learning at English For Food And Beverage Service. This qualitative descriptive research is conducted to obtain information about the current situation. The subjects involved in this study were 60 students from the Hospitality Management study program. The study's data collection was carried out using interviews, questionnaires, and observations with descriptive data analysis methods. The research analysis results show that the implementation of Quizizz is beneficial for students in recalling all the material submitted online and increasing students' interest in learning English. It is supported by the results of the questionnaire analysis, which shows that 78.4\% of students agree that the use of Quizizz attracts their interest in learning English. Only 21.65\% of students feel that they entirely agree. Moreover, none of the students stated that this Quizizz did not increase their interest in attending lectures. So it can be concluded that the Quizizz application is very effectively used to help students in the online learning process and can facilitate evaluating learning by lecturers.

\section{PENDAHULUAN}

Pandemi Covid 19 yang melanda wilayah Indonesia telah memberi dampak pada seluruh aspek kehidupan, termasuk aspek pendidikan. Untuk mengurangi penyebaran virus pada satuan pendidikan pemerintah mengambil kebijakan untuk menutup sekolah, perguruan tinggi maupun universitas termasuk (Kartini et al., 2021; Murniati et al., 2021; Syahabuddin, 2020). Penutupan sekolah ini berdampak pada perubahan proses pembelajaran dari pembelajaran secara langsung (face to face) menjadi pembelajaran jarak jauh (PJJ) (Sugiri \& Pratama, 2020). Pembelajaran jarak jauh, dilaksanakan dengan memanfaatkan media digital yang lebih dikenal dengan istilah E-learning atau pembelajaran dalam jaringan atau daring (Putra, 2020). Pembelajaran daring menjadi solusi terbaik dalam proses pembelajaran jarak jauh ketika terjadi bencana (Syah, 2020). Proses pembelajaran jarak jauh menjadi pendukung kebijakan pelaksanaan Social Distancing untuk membatasi interaksi manusia dan menghindari masyarakat dari kerumunan agar terhindar dari penyebaran virus covid-19 (Aini, 2021; Suhendro, 2020). Perubahan instan dalam proses pembelajaran memaksa setiap tenaga pengajar untuk 
beradaptasi dengan perkembangan teknologi (Salmia \& Yusri, 2021). Para tenaga pendidik diharuskan untuk mampu mencari dan menyusun setiap proses penyampaian materi dengan cara yaang menarik dan atraktif sehingga siswa dapat memahami dan memenuhi capaian pembelajaran.

Kegiatan pembelajaran daring memungkinkan siswa untuk mengikuti kegiatan pembelajaran dimana saja dan kapan saja, sehingga dalam proses pelaksanaannya siswa dapat mengkondisikan diri senyaman mungkin untuk belajar tanpa aturan yang formal, melalui pelaksanaan pembelajaran daring peserta didik juga dapat menghemat waktu serta tenaga dalam melaksanakan proses pembelajaran, sehingga peserta didik memiliki waktu lebih untuk melakukan berbagai macam kegiatan diluar kegiatan akademik, seperti mengikuti lomba, mengikuti les tari atau pengembangan bakat dan minat lainnya (Nugraha et al., 2020; Sobron et al., 2019; Wahyono et al., 2020). Selain itu terdapat berbagai macam manfaat dari pelaksanaan pembelajaran daring diantaranya adalah mampu menciptakan komunikasi yang efektif dan efesien antara guru dengan orang tua siswa, proses interaksi serta komunikasi dapat dilakukan oleh siswa tanpa adanya perantara guru, mempermudah proses interaksi antara guru, siswa, dan orang tua, menjadi salah satu sarana yang cocok digunakan untuk melaksanakan ujian ataupun kuis, mempermudah guru dalam proses pemberian materi pembelajaran, guru dapat dengan mudah menyusun soal, tanpa terkendala waktu dan tempat (Irianti \& Putra, 2021; Telaumbanua, 2021; Yunitasari \& Hanifah, 2020).

Hanya saja pada proses pelaksanaannya terdapat berbagai macam tantangan yang dirasakan oleh guru selama proses pembelajaran daring (Huang et al., 2020; Wiryanto, 2020). Tantangan yang pertama yakni dimana guru-guru memilki waktu yang sangat terbatas dalam menyiapkan dan/ atau menyesuaikan materi pembelajaran luring ke daring (Putri, 2021). Kedua, kurangnya atau terbatasnya kesempatan guru dan siswa dalam berinteraksi secara langsung dan bebas selama pembelajaran daring yang berakibat pada terganggunya proses pembelajaran (Rahmawati et al., 2021). Ketiga, penggunaan pendekatan pedagogi yang efektif memerlukan usaha lebih keras dalam memotivasi serta mengaktifkan siswa dalam pembelajaran secara daring. Tantangan yang dihadapi oleh guru selama proses pembelajaran secara daring, kemudian berdampak pada pelaksanaan evaluasi pembelajaran. Evaluasi merupakan bagian yang tidak terpisahkan dari aktivitas pembelajaran secara keseluruhan (Maftuhin, 2021; Setemen, 2017). Pada umumnya seorang tenaga pengajar atau dosen harus memiliki keterampilan dalam keterampilan melakukan asesmen dan evaluasi agar proses ini dapat berjalan lancar. Dosen mempunyai kewajiban untuk mengukur seberapa dalam siswa telah menguasai ilmu yang sudah dipelajarinya sesuai capaian pembelajaran yang dirumuskan. Proses evaluasi akan terlaksana secara tepat jika disertai dengan proses asesmen sebagai upaya mengungkap seberapa besar kendala yang dihadapi siswa. Proses evaluasi pada kegiatan pembelajaran daring tentu tidak dapat berjalan secara maksimal, hal ini dikarenakan pada saat pembelajaran daring guru/dosen sulit untuk menilai kejujuran siswa dalam menyelesaikan suatu soal tes.

Upaya yang dapat dilakukan untuk mengatasi masalah tersebut yakni merancang media berbasis teknologi, yang dapat memudahkan guru untuk melaksanakan evaluasi bagi siswa. Salah satu media berbasis teknologi yang dapat digunakan yakni media Quizizzz. Quizizz ini menjadi menarik dan efektif karena berbasis teknologi dan kompetitif dengan cara yang atraktif (Mulyati \& Evendi, 2020; Salsabila et al., 2020). Metode ini juga cocok diterapkan di pola pembelajaran online (online) yang secara instan atau langsung juga dapat diketahui hasil dari review (Hidayati \& Aslam, 2021). Penggunaan Quizizzz terbilang praktis dan mudah, dimana penggunanya dibagi kedalam 2 bagian yaitu host (pembuat soal biasanya adalah seorang pengajar dan user (siswa) yang bergabung (join) untuk menjawab soal-soal yang sudah dibuat oleh pengajarnya (Agustina \& Rusmana, 2019; Y. I. Aini, 2019; Darmawan et al., 2020; Irwansyah \& Izzati, 2021). Beberapa penelitian yang telah dilakukan sebelumnya menunjukkan bahwa media aplikasi Quizizz dapat meningkatkan hasil belajar peserta didik, kususnya dalam pembelajaran bahasa (mei et al., 2018). Penelitian lainnya juga menyebutkan bahwa selain membantu siswa dalam mengingat kembali materi yang telah diberikan aplikasi Quizizz juga dapat memunculkan kompetisi diantara para mahasiswa sehingga mereka tertantang untuk menjadi yang terbaik di kelas (Zainuddin et al., 2020). Penelitian berikutnya juga menyebutkan bahwa seluruh peserta didik dapat mencapai ketuntasan dalam evaluasi pembelajaran dikarenakan peserta didik semakin termotivasi untuk bisa mengerjakan quizizz, sehingga pemahaman materi serta hasil belajar peserta didik meningkat (Pusparani, 2020). Berdasarkan beberapa hasil penelitian terdahulu tersebut dapat dikatakan bahwa implementasi Quizizz ini diyakini dapat memotivasi siswa untuk tetap melaksanakan proses pembelajaran, dalam hal ini lebih terfokus pada proses review menjelang evaluasi. Hanya saja pada penelitian sebeumnya belum terdapat kajian mengenai penggunaan Quizizz untuk evaluasi pembelajaran online english for food and beverage service pada program studi Manajemen Perhotelan. Sehingga penelitian ini difokuskan pada hal tersebut dengan tujuan untuk mengidentifikasi bagaimana implementasi Quizizz dalam evaluasi pembelajaran online pada English For Food And Beverage Service. 


\section{METODE}

Jenis penelitian ini adalah penelitian deskriptif kualitatif. Penelitian deskriptif ini dilakukan untuk memperoleh informasi mengenai keadaan saat ini (Mulyatiningsih \& Nuryanto, 2014). Penelitian kualitatif dilakukan karena peneliti ingin mengeksplor fenomena-fenomena yang tidak dapat dikuantifikasikan yang bersifat deskriptif seperti proses suatu langkah kerja, formula suatu resep, pengertian-pengertian tentang suatu konsep yang beragam, karakteristik suatu barang dan jasa, gambargambar, gaya-gaya, tata cara suatu budaya, model fisik suatu artifak dan lain sebagainya (Sato, 2019). Penelitian deskriptif kualitatif ditujukan untuk mendeskripsikan dan menggambarkan fenomenafenomena yang ada, baik bersifat alamiah maupun rekayasa manusia, yang lebih memperhatikan mengenai karakteristik, kualitas, keterkaitan antar kegiatan (Fajri et al., 2020). Selain itu, Penelitian deskriptif tidak memberikan perlakuan, manipulasi atau pengubahan pada variabel-variabel yang diteliti, melainkan menggambarkan suatu kondisi yang apa adanya. Satu-satunya perlakuan yang diberikan hanyalah penelitian itu sendiri, yang dilakukan melalui observasi, wawancara, dan dokumentasi. Dalam penelitian ini, dilakukan identifikasi dan kajian mengenai bagaimana implementasi dari penggunaan aplikasi Quizizz di dalam English for Food and Beverage. Penelitian ini dilaksanakan di kelas Manajemen Perhotelan semester 2 khususnya kelas dengan rotasi Tata Hidang pada mata kuliah Bahasa Inggris Profesi. Subjek dalam penelitian ini adalah 60 mahasiswa dari Institut Pariwisata dan Bisnis Internasional. Sumber data dalam penelitian ini yaitu hasil observasi, wawancara dengan mahasiswa dan dosen, dan kuesioner mengenai respon mahasiswa terhadap penggunaan aplikasi Quizizz di kelas. Sumber data yang diperoleh dapat berupa sumber data primer dan sumber data sekunder. Sumber data primer, yaitu data yang langsung dikumpulkan oleh peneliti dari sumber pertamanya. Adapun yang menjadi sumber data primer dalam penelitian ini adalah hasil wawancara dan kuesioner dengan mahasiswa Manajemen Perhotelan. Sumber data sekunder, yaitu data yang langsung dikumpulkan oleh peneliti sebagai penunjang darii sumber yang pertama. Dapat juga dikatakan data yang tersusun dalam bentuk dokumendokumen, dan dalam penelitian ini dokumentasi merupakan sumber data sekunder.

Dalam prosese pengumpulan data digunakan beberapa metode dan instrument dalam penelitian ini yaitu: wawancara, survey dan dokumentasi. Wawancara dalam penelitian ini dilakukan untuk mengetahui respon mahasiswa dan implementasi penggunaan Quizizz di kelas. Dalam penelitian ini digunakan wawancara terstruktur sehingga sebelum melakukan wawancara telah disiapkan beberapa daftar pertanyaan. Survey dalam penelitian ini menggunakan kuesioner. Kuesioner digunakan untuk mengetahui respon mahasiswa terhadap penggunaan Quizizz. Kuesioner berisi pernyataan-pernyataan yang nantinya akan dinilai oleh mahasiswa sesuai dengan apa yang mereka rasakan dan mereka alami. Pernyataan-pernyataan yang dinilai oleh mahasiswa akan dilihat hasilnya menjadi kategori setuju dan tidak setuju. Pernyatan yang tercantum dalam kuesioner dibuat berdasarkan terori evaluasi dan pembelajaran bahasa. Dokumentasi dalam penelitian ini adalah data yang diperoleh dari analisis dokumen dapat digunakan sebagai data pendukung dan pelengkap bagi data primer yang diperoleh melalui wawancara dan kuesioner. Setelah data terkumpul melalui wawancara, penyebaran kuesioner dan beberapa dokumentasi, dilanjutkan dengan proses data reduction (reduksi data). Semua data yang terkumpul diseleksi dan diklasifikasi berdasarkan kebutuhan. Data yang tidak perlu dapat dihilangkan. Fokus data berdasarkan rumusan masalah yaitu bagaimana implementasi penggunaan Quizizz. Langkah selanjutnya adalah data display (penyajian data) yaitu menyusun data yang telah diseleksi sehingga dapat terlihat apa saja temuan-temuan yang didapatkan. Setelah diperoleh hasi wawancara, kuesioner secara terpadu, maka dbuatlah kesimpulan (conclusion) untuk masalah yang telah dirumuskan, sehingga dapat dilihat bagaimana pelaksanaan Quizizz dan langkah-langkah pelaksanaanya. Adapun langkah-langkah analisis data dapat dilihat pada Gambar 1.

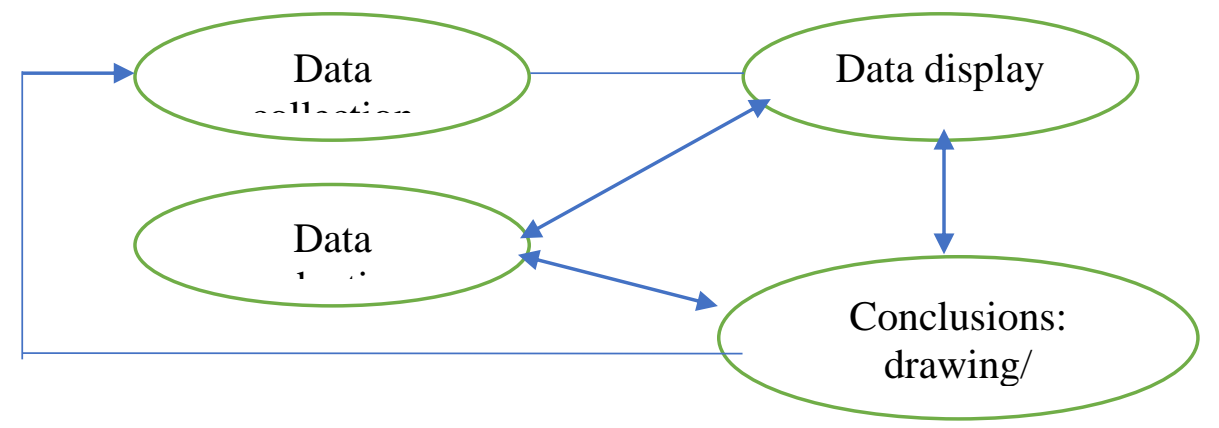

Gambar 1. Model Analisis data (Miles et al., 2014) 


\section{HASIL DAN PEMBAHASAN}

\section{Hasil}

Dalam implementasi penggunaan Quizizz, model pertanyaan dirancang dengan melibatkan semua aspek bahasa yang harus dicapai di akhir pembelajaran. Sebelum data diperoleh, peneliti menyiapkan instrumen yang diperlukan seperti kuesioner, dan daftar pertanyaan wawancara yang akan digunakan. Sebelumnya, mahasiswa sudah mendapatkan beberapa materi yang disampaikan secara online oleh dosen. Setelah pertemuan ke 15, mahasiswa diharapkan sudah menguasai semua materi yang dipaparkan pada pertemuan sebelumnya. Untuk memulai penggunaan aplikasi Quizizz, dosen harus menyiapkan pertanyaan-pertanyaan yang sesuai dengan materi yang telah disampaikan sebelumnya. Materi-materi yang menjadi fokus harus dimunculkan pada pertanyaan-pertanyaan di Quizizz untuk mengingatkan kembali materi tersebut. Contoh pertanyaan dalam pembelajaran English for Food and Beverage disajikan pada Gambar 2. Gambar 2 menunjukkan satu bentuk pertanyaan untuk English for Food and Beverage yang menekankan pada respon dalam berkomunikasi dengan tamu di restoran. Setelah pertanyaan disiapkan, dosen mengirimkan link atau kode kepada mahasiswa. Setelah dibagikan mahasiswa dapat mengerjakan soal-soal melalui link atau kode akses yang diberkan dan dapat mengerjakan sesuai waktu yang disediakan. Hasil test yang diperoleh mahasiswa akan langsung muncul. Bentuk link, code, serta tampilan peringkat siswa disajikan pada Gambar 3 dan 4.

Setelah mahasiswa menyelesaikan Quizizz, maka akan muncul secara otomatis nilai yang mereka dapatkan. Dosen dapat melihat peringkat mahasiswa dengan nilai tertinggi dan terendah tanpa perlu memeriksa satu per satu jawaban mereka. Pengumpulan data dilanjutkan dengan penyebaran kuesioner. Dalam penelitian ini, terlibat 2 kelas yang masing-masing terdiri dari 25 orang. Sehingga data kuesioner diperoleh dari 60 responden dari kelas Manajemen Perhotelan semester 2. Hasil sebaran kuesioner untuk respon mahasiswa terhadap penggunaan Quizizz, disajikan pada Gambar 5. Respon mahasiswa terhadap penggunaan Quiziz sangat baik. Dapat dilihat dari presentase 78,4 \% mahasiswa menyatakan setuju untuk penggunaan Quizizz menarik minat mereka untuk belajar bahasa Inggris. Hanya 21,65 mahasiswa yang merass cukup setuju. Dan tidak ada mahasiswa yang menyatakan bahwa Quizizz ini tidak meningkatkan minat mereka untuk mengikuti perkuliahan.

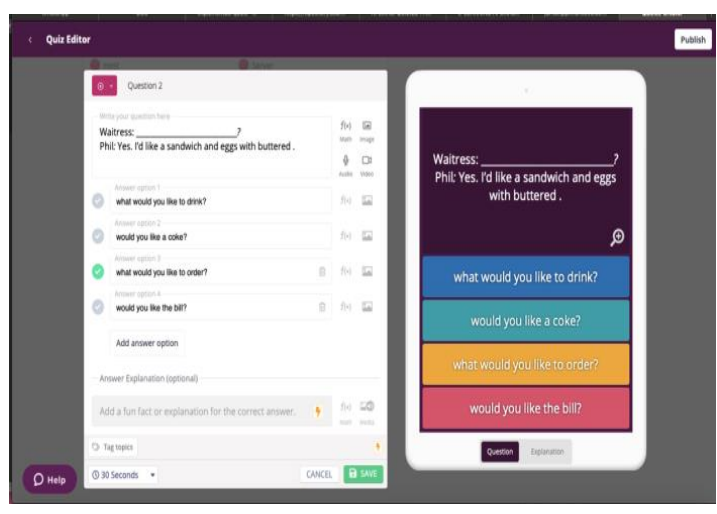

Gambar 2. Tampilan pertanyaan di Quizizz

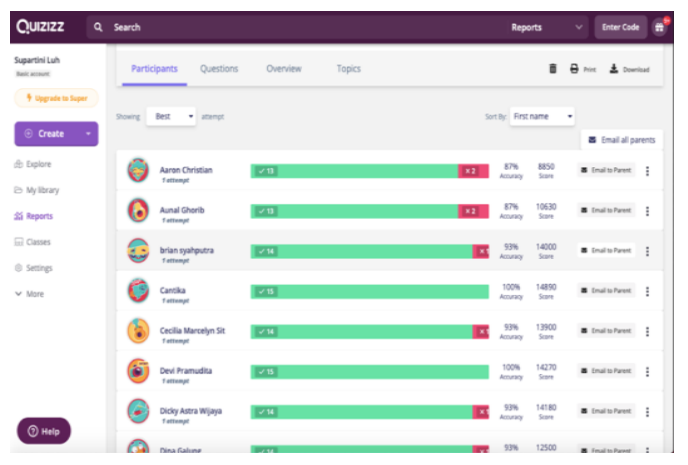

Gambar 4. Tampilan peringkat mahasiswa

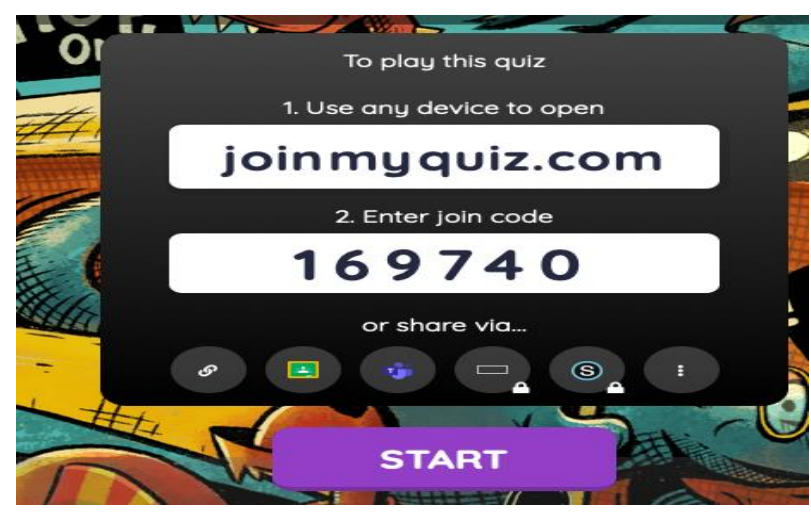

Gambar 3. Quizizz link dan kode

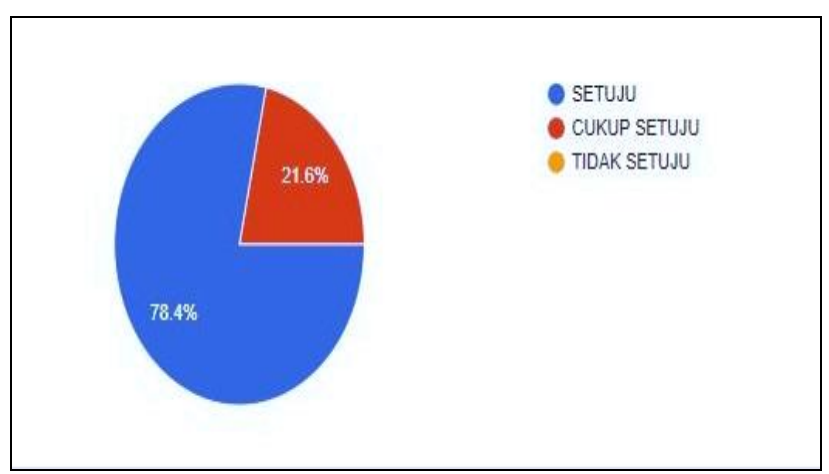

Gambar 5. Presentase respon siswa terhadap penggunaan Quizizz 


\section{Pembahasan}

Hasil penyebaran kuesioner serta wawancara yang telah dilakukan menunjukkan bahwa dengan menggunakan Quizizz, pembelajaran bahasa Inggris menjadi lebih menarik, dimana sebelum penggunaan Quizizz, belajar Bahasa Inggris sangat membosankan dengan tugas-tugas yang banyak tanpa mereka pahami. Hal ini dikarenakan pembelajaran dengan menggunakan Quizizz mampu melatih siswa untuk mengerjakan tes secara cermat, sehingga mampu meningkatkan pemahaman serta daya ingat mahasiswa (Noor, 2020; Zhao, 2019). Melalui Quizizz Mahasiswa dapat mengaplikasikan pengetahuan mereka menggunakan gadget, selain itu penggunaan Quizizz juga dapat digunakan sebagai strategi pembelajaran yang baik dan menyenangkan tanpa kehilangan esensi belajar yang sedang barlangsung (Amri \& Shobri, 2020). Strategi Quizizz dapat melibatkan partisipasi siswa secara aktif sejak awal, sehingga mampu menciptakan pembelajaran yang kreatif dan menyenangkan (Chaiyo \& Nokham, 2017). Aplikasi Quizizz memberikan kesempatan bagi para dosen untuk merancang model kuis secara bebas, sehingga materi Bahasa Inggris yang disampaikan dapat diingat kembali oleh mahasiswa (Lusiani, 2020; Samsinar et al., 2021). Kuis interaktif ini memiliki hingga 4-5 pilihan jawaban termasuk jawaban yang benar. Bisa juga ditambahkan gambar ke latar belakang pertanyaan dan menyesuaikan pengaturan pertanyaan sesuai keinginan anda. Bila kuis sudah jadi, dapat dibagikan kepada siswa dengan menggunakan kode 6 digit atau dengan membagikan tautannya. Bagi mahasiswa, pertanyaan yang sudah disiapkan dalam Quizizz sangat membantu mereka dalam mengingat kembali materi yang mereka pelajari sebelumnya (Ekayana, 2021; Mulatsih, 2020). Hasil kuisioner menunjukkan 70,6\% menunjukkan bahwa aplikasi ini bisa membantu daya ingat mereka untuk mengingat materi yang telah disampaikan sebelumnya. Dengan variasi gambar, pilihan jawaban menjadi petunjuk mereka untuk menjawab semua pertanyaan dengan benar. Dalam aplikasi Quiziz disediakan berbagai jenis pertanyaan mulai dari pilihan ganda, jawaban singkat dan essay (Salsabila et al., 2020; Supriadi et al., 2021). Pada aplikasi juga terdapat fitur pembahasan untuk setiap pertanyaan yang disajikan, sehingga dosen dapat menggunakan fitur ini untuk mengetahui materi yang belum dipahami oleh mahasiswa (Pusparani, 2020). Tampilan ini menunjukkan pertanyaan yang paling banyak dijawab salah dan benar, sehingga dosen dapat membahas kembali materi tersebut (Utomo et al., 2021). Jika pertanyaan tersebut dijawab salah oleh seluruh mahasiswa, ini kemungkinan terjadi kesalahan pada pertanyaan yang disiapkan. Dosen sangat mudah memonitor setiap pertanyaan dan jawaban dari masing-masing mahasiswa. Fitur pembahasan juga sangat membantu dalam membuat perkembangan hasil belajar murid sehingga dapat terpantau dengan mudah. Selain itu pada aplikasi Quizizz setiap siswa mendapatkan soal yang berbeda- beda, karena telah diacak secara otomatis, sehingga meminimalisir kecurangan (Salsabila et al., 2020).

Penggunaan aplikasi Quizizz dalam proses evaluasi pembelajaran English for Food and Beverage Service dirasa sangat sesuai, hal ini dikarenakan pada pembelajaran English for Food and Beverage Service mahasiswa dituntut untuk dapat memahami kosakata, kalimat dan ungkapan yang tepat bagi seorang pramusaji di restoran. Berbagai kosakata terkait restoran dapat disajikan dengan memberikan pertanyaan dengan gambar-gambar. Untuk dapat berkomunikasi yang baik dengan tamu, mahasiswa dapat diberikan pertanyaan dalam bentuk isian ataupun pilihan ganda dalam menentukan ungkapan yang tepat dalam Bahasa Inggris. Hasil yang diperoleh pada penelitian ini sejalan dengan hasil penelitian terdahulu yang juga mengungkapkan bahwa media aplikasi Quizizz dapat meningkatkan hasil belajar peserta didik, kususnya dalam pembelajaran bahasa (mei et al., 2018). Penelitian lainnya juga menyebutkan bahwa selain membantu siswa dalam mengingat kembali materi yang telah diberikan aplikasi Quizizz juga dapat memunculkan kompetisi diantara para mahasiswa sehingga mereka tertantang untuk menjadi yang terbaik di kelas (Zainuddin et al., 2020). Penelitian berikutnya juga menyebutkan bahwa seluruh peserta didik dapat mencapai ketuntasan dalam evaluasi pembelajaran dikarenakan peserta didik semakin termotivasi untuk bisa mengerjakan quizizz, sehingga pemahaman materi serta hasil belajar peserta didik meningkat (Pusparani, 2020). Berdasarkan beberapa hasil penelitian tersebut dapat dikatakan bahwa implementasi Quizizz dapat memotivasi siswa untuk tetap melaksanakan proses pembelajaran, dalam hal ini lebih terfokus pada proses review menjelang evaluasi.

\section{SIMPULAN}

Implementasi aplikasi Quizizz dalam pembelajaran English for Food and Beverage sangat menarik bagi mahasiswa untuk mengikuti pembelajaran secara online, namun dalam English for Food and Beverage, implementasi Quizizz tidak dapat digunakan untuk mengevaluasi kemampuan berbicara mahasiswa. 


\section{DAFTAR PUSTAKA}

Agustina, L., \& Rusmana, I. M. (2019). Pembelajaran Matematika Menyenangkan dengan Aplikasi Kuis Online Quizizz. Prosiding Seminar Nasional Matematika Dan Pendidikan Matematika Sosiomadika, 1-7. https://journal.unsika.ac.id/index.php/sesiomadika /article/view/2249.

Aini, K. (2021). Analisis Proses Pembelajaran Daring pada Masa Pandemi Covid 19. Jurnal Studi Guru Dan Pembelajaran, 4(1). https://doi.org/10.30605/jsgp.4.1.2021.585.

Aini, Y. I. (2019). Pemanfaatan Media Pembelajaran Quizizz Untuk Pembelajaran Jenjang Pendidikan Dasar Dan Menengah Di Bengkulu. Jurnal Kependidikan, 2(25), 1-6. http://jurnal.umb.ac.id/index.php/kependidikan/article/view/567.

Amri, M., \& Shobri, Y. A. (2020). Persepsi Mahasiswa Terhadap Penggunaan Quizizz Dalam Pembelajaran Akuntansi Konsolidasi Bank Syariah Di Iain Ponorogo. Jurnal Teknologi Informasi Dan Pendidikan, 13(1). https://doi.org/10.24036/tip.v13i1.

Chaiyo, Y., \& Nokham, R. (2017). The effect of Kahoot, Quizizz and Google Forms on the student's perception in the classrooms response system. 2017 International Conference on Digital Arts, Media and Technology (ICDAMT), 178-182. http://ieeexplore.ieee.org/document/7904957/.

Darmawan, M. S., Daeni, F., \& Listiaji, P. (2020). The Use of Quizizz As an Online Assessment Application for. Unnes Science Education Journal, 9(3), 144-150. https://doi.org/10.15294/USEJ.V9I3.41541.

Ekayana, A. A. G. (2021). User Experience Penggunaan Google Classroom dan Quizizz dalam Pembelajaran Blended Learning Program Studi Sistem Komputer. Jurnal Ilmu Pendidikan (JIP) STKIP Kusuma Negara, 13(1), 23-34. https://doi.org/10.37640 /jip.v13i1.939.

Fajri, D. N., Yuliati, N., \& Budyawati, L. P. I. (2020). Analisis Pelaksanaan Asesmen Perkembangan Anak. Jurnal Edukasi, 7(2), 17. https://doi.org/10.19184 /jukasi.v7i2.22680.

Hidayati, I. D., \& Aslam, A. (2021). Efektivitas Media Pembelajaran Aplikasi Quizizz Secara Daring Terhadap Perkembangan Kognitif Siswa. Jurnal Pedaagogi Dan Pembelajaran, 4(1). https: //doi.org/10.23887/jp2.v4i2.37038.

Huang, R. H., Liu, D. J., Tlili, A., Yang, J. F., \& Wang, H. H. (2020). Handbook on facilitating flexible learning during educational disruption: The Chinese experience in maintaining undisrupted learning in COVID-19 outbreak. In Beijing: Smart Learning Institute of Beijing Normal University.

Irianti, M., \& Putra, T. Y. (2021). Analisis Persepsi Mahasiswa Unimuda Sorong Terhadap Pembelajaran Daring Selama Masa Covid-19. Jurnal Pendidikan, $9(2)$. https://doi.org/10.36232/pendidikan.v9i2.1100.

Irwansyah, R., \& Izzati, M. (2021). Implementing Quizizz as Game Based Learning and Assessment in the English Classroom. TEFLA Journal (Teaching English as Foreign Language and Applied Linguistic Journal), 3(1), 13-18. https://journal.umbjm.ac.id /index.php/TEFLA/article/view/756.

Kartini, E., Mimbar, L., \& Izrawati. (2021). Tantangan Dalam Pembelajaran Perguruan Tinggi Dan Implementasi Merdeka Belajar Di Masa Pandemi Covid-19. Journal Ilmiah Rinjani: Media Informasi Ilmiah Universitas Gunung Rinjani, 9(2), 43-50. https://doi.org/10.53952/jir.v9i2.321.

Lusiani, L. (2020). Penggunaan Aplikasi Online Quizizz dalam Menganalisis Hasil Tes Kognitif Siswa pada Materi Energi. Science, and Physics Education Journal (SPEJ), 4(1), 15-23. https://doi.org/10.31539/spej.v4i1.1637.

Maftuhin. (2021). Analysis of Arabic Learning Evaluation Using Blanded Learning Method at Senior High School of Al-Izzah Batu/ Analisa Evaluasi Pembelajaran Bahasa Arab dengan Menggunakan Model blanded Learning di SMA Al-Izzah Batu. JALSAT: Journal Of Arabic Language Studies And Teaching, 1(1). https://doi.org/10.15642/jalsat.v1i1.45.

mei, S. Y., Ju, S. Y., \& Adam, Z. (2018). Implementing Quizizz as Game Based Learning in the Arabic Classroom. European Journal of Social Sciences Education and Research, 12(1), 208. https: //doi.org/10.26417/ejser.v12i1.p208-212.

Miles, M. B., Huberman, A. M., \& Saldana, J. (2014). Qualitative data analysis: A methods sourcebook.

Mulatsih, B. (2020). Application Of Google Classroom, Google Form And Quizizz In Chemical Learning During The Covid-19 Pandemic. Ideguru: Jurnal Karya Ilmiah Guru, 5(1). https://doi.org/10.51169/ideguru.v5i1.129.

Mulyati, S., \& Evendi, H. (2020). Pembelajaran Matematika melalui Media Game Quizizz untuk Meningkatkan Hasil Belajar Matematika SMP. GAUSS: Jurnal Pendidikan Matematika, 3(1), 64-73. https://doi.org/10.30656/gauss.v3i1.2127.

Mulyatiningsih, E., \& Nuryanto, A. (2014). Metode penelitian terapan bidang pendidikan.

Murniati, R. F., Gis, M., \& Nuwaswita, L. (2021). Dilematis Antara Kesulitan Siswa Dengan Guru Dalam Pembelajaran Daring Pada Masa Pandemic Covid-19: Sebuah Upaya Aksidental MTs. Muhammadiyah Wuring Authors. Naturalistic: Jurnal Kajian Penelitian Dan Pendidikan Dan 
Pembelajaran, 6(1). https://doi.org/10.35568/naturalistic.v6i1.902.

Noor, S. (2020). Penggunaan quizizz dalam penilaian pembelajaran pada materi ruang lingkup biologi untuk meningkatkan hasil belajar siswa kelas X. 6 SMAN 7 Banjarmasin. Jurnal Pendidikan Hayati, 6(1), 1-7. https://doi.org/10.33654/jph.v1i1.927.

Nugraha, S. A., Sudiatmi, T., \& Suswandari, M. (2020). Studi Pengaruh Daring Learning Terhadap Hasil Belajar Matematika Kelas IV. Jurnal Inovasi Penelitian, 1(3), 265-276. https://doi.org/10.47492/jip.v1i3.74.

Pusparani, H. (2020). Media Quizizz Sebagai Aplikasi Evaluasi Pembelajaran Kelas VI DI SDN Guntur Kota Cirebon. Tunas Nusantara, 2(2), 269-279. https://doi.org/10.34001/jtn.v2i2.1496.

Putra, N. P. (2020). Solusi Pembelajaran Jarak Jauh Menggunakan Aplikasi Zoom Dan Whatsapp Group Di Era New Normal Pada Warga Belajar Paket C Di Pusat Kegiatan Belajar Masyarakat (PKBM) Bina Insani. JIPSINDO, 7(2), 162-176. https://doi.org/10.21831/jipsindo.v7i2.34939.

Putri, A. S. I. (2021). Kemampuan Guru PAUD dalam Mengelola Pembelajaran pada Masa Pandemi Covid19. Jurnal Pendidikan Anak Usia Dini Undiksha, 9(1), 23. https://doi.org/10.23887/paud.v9i2.35508.

Rahmawati, A., Pina, E. Al, Setiono, P., Yuliantini, N., \& Wurjinem, W. (2021). Kesulitan Guru Dalam Pembelajaran Tematik Di Kelas V SD Negeri 38 Kota Bengkulu Selama Pembelajaran Daring. Elementary School: Jurnal Pendidikan Dan Pembelajaran Ke-SD-An, 8(2), 303-309. https://doi.org/10.31316/esjurnal.v8i2.1398.

Salmia, S., \& Yusri, A. M. (2021). Peran Guru Dalam Pembelajaran Abad 21 Di Masa Pandemik Covid-19. Indosian Jurnal of Primary Education, 5(1). https://doi.org/10.17509/ijpe.v5i1.31955.

Salsabila, U. H., Habiba, I. S., Amanah, I. L., Istiqomah, N. A., \& Difany, S. (2020). Pemanfaatan Aplikasi Quizizz Sebagai Media Pembelajaran Ditengah Pandemi Pada Siswa SMA. Jurnal Ilmiah Ilmu Terapan Universitas Jambi|JIITUJ/, 4(2), 163-173. https://doi.org/10.22437/jiituj.v4i2.11605.

Samsinar, S., Juanita, S., \& Anif, M. (2021). Peningkatan Kualitas Guru di Masa Pandemi Covid-19 dengan Pelatihan Aplikasi Quizizz. ABDI MOESTOPO: Jurnal Pengabdian Pada Masyarakat, 4(02), 57-64. https://doi.org/10.32509/abdimoestopo.v4i02.1402.

Sato, T. (2019). Elementary physical educators' positioning in teaching English language learners. $\begin{array}{llll}\text { European Physical } & \text { Education 203-220. }\end{array}$ https://doi.org/10.1177/1356336X17715771.

Setemen, K. (2017). Pengembangan evaluasi pembelajaran online. Jurnal Pendidikan Dan Pengajaran, 43(3). https://doi.org/10.23887/jppundiksha.v43i3.124.

Sobron, Bayu, Rani, \& S, M. (2019). Pengaruh Daring Learning terhadap Hasil Belajar IPA Siswa Sekolah Dasar. Prosiding Seminar Nasional Dan Enterpreneurship, 1-5. http://conference.upgris.ac.id/index.php/snse/article/view/204.

Sugiri, D., \& Pratama, A. A. (2020). Aktivitas Pembentukan Biaya Layanan Pembelajaran Jarak Jauh (PJJ) sebagai dampak Pandemi Covid-19. Edumaspul: Jurnal Pendidikan, 4(2). https://doi.org/10.33487/edumaspul.v4i2.678.

Suhendro, E. (2020). Strategi Pembelajaran Pendidikan Anak Usia Dini di Masa Pandemi Covid-19. Golden Age: Jurnal Ilmiah Tumbuh Kembang Anak Usia Dini, 5(9), 133-140. http://ejournal.uinsuka.ac.id/tarbiyah/goldenage/article/download/3394/1884/.

Supriadi, N.-, Tazkiyah, D., \& Isro, Z. (2021). Penerapan Aplikasi Quizizz Dalam Pembelajaran Daring Di Era Covid-19. Jurnal Cakrawala Mandarin, 5(1), 42. https://doi.org/10.36279/apsmi.v5i1.101.

Syah, R. H. (2020). Dampak Covid-19 pada Pendidikan di Indonesia: Sekolah, Keterampilan, dan Proses Pembelajaran. SALAM: Jurnal Sosial Dan Budaya Syar-I, 7(5), 395. https://doi.org/10.15408/sjsbs.v7i5.15314.

Syahabuddin, K. (2020). Teacher-student relationships: An influence on the english teaching-learning process. Studies in English Language and Education, 7(2), 393-406. https://doi.org/10.24815/siele.v7i2.16922.

Telaumbanua, Y. N. (2021). Pembelajaran Matematika Secara Daring Akibat Pandemi Corona Virus Diseases 2019. Jurnal Review Pendidikan Dan Pengajaran, 3(2), 445-449. https://doi.org/10.31004/jrpp.v3i2.1692.

Utomo, M. C. C., Putra, M. G. L., \& Prambudi, D. A. (2021). Perbandingan Fitur Pada Platform Kuis Terpopuler. Inspiration: Jurnal Teknologi Informasi Dan Komunikasi, 11(1), 38. https://doi.org/10.35585/inspir.v11i1.2596.

Wahyono, P., Husamah, H., \& Budi, A. S. (2020). Guru profesional di masa pandemi COVID-19: Review implementasi, tantangan, dan solusi pembelajaran daring. Jurnal Pendidikan Profesi Guru, 1(1), 51-65. https://doi.org/10.22219/jppg.v1i1.12462.

Wiryanto, W. (2020). Proses Pembelajaran Matematika Di Sekolah Dasar Di Tengah Pandemi Covid-19. 
Jurnal Review Pendidikan Dasar, 6(2). https://doi.org/10.26740/jrpd.v6n2.p125-132.

Yunitasari, R., \& Hanifah, U. (2020). Pengaruh Pembelajaran Daring terhadap Minat Belajar Siswa pada Masa COVID-19. Edukatif: Jurnal Ilmu Pendidikan, 2(3), 232-243. https://doi.org/10.31004/edukatif.v2i3.142.

Zainuddin, Z., Shujahat, M., Haruna, H., \& Chu, S. K. W. (2020). The role of gamified e-quizzes on student learning and engagement: An interactive gamification solution for a formative assessment system. Computers \& Education, 145, 103729. https://doi.org/10.1016/j.compedu.2019.103729.

Zhao, F. (2019). Using quizizz to integrate fun multiplayer activity in the accounting classroom. International Journal of Higher Education, 8(1), 37-43. https://doi.org/10.5430/ijhe.v8n1p37. 